\title{
Frequent contact allergens in Ankara/Turkey: A retrospective study of patch test results
}

\author{
Türkiye/Ankara ilinde sık görülen kontakt allerjenler: \\ Yama testi sonuçlarını içeren retrospektif bir çalıșma
}

\section{Mustafa Tunca, ๑ Ercan Çalıșkan, ๑ Aslan Yürekli*}

University of Health Sciences, Gülhane Faculty of Medicine, Department of Dermatology, Ankara, Turkey

*Bayburt Public Hospital, Clinic of Dermatology, Bayburt, Turkey

\begin{abstract}
Background and Design: Allergic contact dermatitis is a delayed (type 4) reaction against external contact agents. It occurs within $48-96$ hours after re-contact of allergen with pre-sensitized skin.

Materials and Methods: There are many allergens on earth that are not in protein structure. Paints, oils, resins, chemicals used in the textile industry, rubber, cosmetics, insecticides, plants, bacteria, fungi and parasites can cause allergic contact dermatitis. Patch test is the gold standard for diagnosis and provides valuable results when evaluated according to history and physical examination findings. In this study, we evaluated the patch test results of 673 patients.

Results: The most common allergens in our study were nickel sulfate (18.3\%), cobalt chloride (5.1\%), potassium dichromate (4.8\%), thiuram mix (4.3\%), p-phenylenediamine (3.7\%) and formaldehyde (2.5\%).

Conclusion: In order to obtain more and more accurate information about the most common contact allergens in our country, we believe that there is a need for studies in different centers and at different time intervals. This is why we want share this study that we conducted in Ankara/Turkey.
\end{abstract}

Keywords: Contact dermatitis, patch test, nickel

Öz

Amaç: Allerjik kontakt dermatit, dış etkenlere karşı oluşan gecikmiş (tip 4) bir reaksiyondur. Allerjenin önceden duyarlı hale gelmiş deri ile tekrar temasından sonra 48-96 saat içinde ortaya çıkar.

Gereç ve Yöntem: Yeryüzünde, protein yapısında olmayan bir çok allerjen vardır. Tekstil endüstrisinde kullanılan boyalar, yağlar, reçineler, kimyasal maddeler, kauçuk, kozmetik, böcek öldürücüler, bitkiler, bakteri, mantar ve parazitler allerjik kontakt dermatite neden olabilir. Yama testi, teşhis için altın standarttır. Öykü ve fizik muayene bulgularına göre değerlendirildiğinde çok değerli sonuçlar verir. Bu çalışmada 673 hastanın yama testi sonuçları değerlendirildi.

Bulgular: Çalışmamızda en sık rastlanan allerjenler, nikel sülfat $(\% 18,3)$, kobalt klorür $(\% 5,1)$, potasyum dikromat $(\% 4,8)$, tiuram karışımı $(\% 4,3)$, p-fenilendiamin $(\% 3,7)$ ve formaldehit $(\% 2,5)$ olarak bulundu.

Sonuç: Ülkemizde en sık rastlanan kontakt allerjenler hakkında daha fazla ve daha doğru bilgi edinebilmek için; farklı merkezlerde ve farklı zaman aralıklarında yapılan çalışmalara intiyaç olduğunu düşünmekteyiz. Bu sebeple Türkiye'de Ankara ili ve yöresinde yaptığımız bu çalışmayı paylaşmak istedik.

Anahtar Kelimeler: Kontakt dermatit, yama testi, nikel

\section{Introduction}

Allergic contact dermatitis (ACD) is a common dermatological disorder caused by contact allergy to a wide spectrum of natural or manmade substances of low molecular weight (haptens or allergens). In cross sectional studies, some 20 to $30 \%$ of the general population has been diagnosed to have contact allergy to at least one allergen'. For the diagnosis of contact allergy, the patch test is the gold

Address for Correspondence/Yazışma Adresi: Mustafa Tunca MD, University of Health Sciences, Gülhane Faculty of Medicine, Department of Dermatology, Ankara, Turkey Phone: +90 5337422687 E-mail: mustafatunca@hotmail.com Received/Geliş Tarihi: 31.10.2017 Accepted/Kabul Tarihi: 28.08.2018 ORCID ID: orcid.org/0000-0003-4253-5110 
standard. Epidemiological studies indicated that there are differences in the incidences of contact allergens in different populations. The examination of patch test results give us the opportunity to find out the most common allergens and, also factors affecting the frequency of these allergens. If the allergens causing ACD in a specific population is known, it is possible to exert primary prevention programs to reduce the risk for $A C D$ by limiting or avoiding the general use of common allergens in this population. This retrospective study aimed to find out the most common sensitizers in Ankara Turkey and near region and to evaluate other factors affecting contact allergy in our country.

\section{Materials and Methods}

The patch test results of 673 patients with suspected ACD who were patch tested in our hospital using the European Standard Series in the years between 2001 and 2015 were analyzed retrospectively. European Standard Series include 28 allergens. And these allergens are applied to patients using IQ Chambers (Chemotechnique Diagnostics, Sweden). Each patch is carefully numbered or labelled so the allergen in each chamber can be correctly identified. In this this retrospective evaluation attention was paid to the following conditions and the files of the patients who fulfilled these conditions were taken into consideration: Patients who were taking any influencing drugs, immunosuppressive agents, were not tested unless they stop these medications and had at least 4 weeks of drug free period, for antihistamines this period evaluated for 7 days drug free period. Also, the patients who applied corticosteroids in the last month to the test site were not tested. The allergens were applied with Finn Chambers to the upper back of the patients and left for 48 hours. The results were evaluated by an experienced dermatologist and positive reactions were recorded. The study was approved by the Gülhane Military Medical Academy Command Ethics Committee (approval number: 314, date: 09.07.2015). Informed consent forms were taken before the study.

\section{Statistical Analysis}

The degree of positivity was not taken into account in statistical analyses. The chi-square test was used to compare between the groups. The exact binomial test was also used to compare between the groups. P value of 0.05 or less was considered significant. Statistical analysis of the collected data was performed with SPSS, version 14 (SPSS Inc., Chicago, IL, USA).

\section{Results}

Among the 673 patients tested with European Standard Patch Test Series, 377 patients were females (56\%) and 296 patients were males (44\%). The mean age of the patients was $29.4 \pm 10.3$, ranging from 5 to 65 years.

When considered according to occupation the largest groups were office workers (33.4\%), and soldiers (21.8\%). Unoccupied patients including housewives, retirees or unemployed comprised $18.4 \%$. Health care workers were the fourth largest group with 8.5\%.

A total of 253 patients (37.6\%) had one or more positive patch test reactions. The most common allergens were nickel sulphate $(18.3 \%)$, cobalt chloride $(5.1 \%)$, potassium dichromate $(4.8 \%)$, thiuram mix
(4.3\%), p-phenylenediamine (3.7\%), and formaldehyde (2.5\%). Other allergens caused reactions in less than $2 \%$ of the patients.

When grouped according to sex, $42.4 \%$ of females and $31.4 \%$ of males had positive reactions to at least one allergen. Among females nickel sulphate $(28.6 \%)$, cobalt chloride (5.6\%), p-phenylenediamine (4.8\%), thiuram mix (4.5\%), formaldehyde (2.9\%) and fragrance mix $(2.4 \%)$ were the most prevalent allergens. Among men potassium dichromate $(8.8 \%)$, nickel sulphate $(5.1 \%)$, cobalt chloride $(4.4 \%)$, thiuram mix (4.1\%), p-phenylenediamine (2.4\%) and formaldehyde (2.0\%) were the most common allergens.

Contact sensitivity to nickel, p-phenylenediamine and fragrance mix was significantly more frequent in female patients and contact sensitivity to potassium dichromate was significantly more frequent in male patients. The frequency of positive patch test reactions and its distribution according to sex is shown in Table 1.

The hands (45.5\%), face (16.2\%) and legs (13.7\%) were the most frequent sites affected by dermatitis.

There was a history of atopy in 177 (26.3\%) patients. In this group (ie. atopics) a positive reaction to one or more allergens was noted in $41.8 \%$. In non-atopics this figure was $37.6 \%$. The difference between the sensitivity rates of the Standard Series Allergens were not statistically significant in atopic patients compared to non-atopic patients $(p=0.8)$.

\section{Discussion}

Nickel was the most common contact allergen in our study. Nickel sulphate has been reported to be the most common contact allergen in previous studies from different centers in Turkey and in other studies around the world ${ }^{2-6}$. In all these studies sensitivity to nickel sulphate is reported to be higher among women.

In previous studies from Turkey, prevalence of nickel sensitivity ranged from $12.2 \%$ to $19.1 \%{ }^{2-4}$. Bruynzeel et al. ${ }^{7}$ reported patch test results of 26210 patients from 10 centres in 7 European countries on behalf of The European Environmental and Contact Dermatitis Research Group. They reported the average nickel sensitivity in these centers to be $17.9 \%$, ranging from $12.7 \%$ to $24.6 \%$. In 2005 Uter et al. ${ }^{8}$ reported

Table 1. The frequency of positive patch test reactions

\begin{tabular}{|l|l|l|l|l|l|l|}
\hline & $\begin{array}{l}\text { Total= } \\
\mathbf{6 7 3}\end{array}$ & $\mathbf{6}$ & $\begin{array}{l}\text { Female } \\
\mathbf{n = 3 7 7}\end{array}$ & $\%$ & $\begin{array}{l}\text { Male } \\
\mathbf{n = 2 9 6}\end{array}$ & $\%$ \\
\hline Nickel sulfate & 123 & 18.3 & 108 & 28.6 & 15 & 5.1 \\
\hline Cobalt chloride & 34 & 5.1 & 21 & 5.6 & 13 & 4.4 \\
\hline $\begin{array}{l}\text { Potassium } \\
\text { dichromate 0.5\% }\end{array}$ & 32 & 4.8 & 6 & 1.6 & 26 & 8.8 \\
\hline Thiuram mix 1\% & 29 & 4.3 & 17 & 4.5 & 12 & 4.1 \\
\hline $\begin{array}{l}\text { p-Phenylenediamine } \\
\text { 1\% }\end{array}$ & 25 & 3.7 & 18 & 4.8 & 7 & 2.4 \\
\hline Formaldehyde & 17 & 2.5 & 11 & 2.9 & 6 & 2.0 \\
\hline Paraben mix & 11 & 1.6 & 6 & 1.6 & 5 & 1.7 \\
\hline Fragrance mix & 11 & 1.6 & 9 & 2.4 & 2 & 0.7 \\
\hline $\begin{array}{l}\text { N-isopropyl-N-phenyl- } \\
\text { p-phenylenediamine }\end{array}$ & 10 & 1.5 & 6 & 1.6 & 4 & 1.4 \\
\hline $\begin{array}{l}\text { Neomycin sulfate } \\
\text { 20\% }\end{array}$ & 7 & 1.0 & 2 & 0.5 & 5 & 1.7 \\
\hline
\end{tabular}


first results of the European Surveillance System on Contact Allergies (ESSCA), which contained the results of patch tests performed in 2002 and 2003 in 17 centers from 9 European countries. In this study, positive reaction to nickel was $17.3 \%$, however, large international variations were observed, ranging from 8.1 to $31.7 \%$ among centers. According to data collected by ESSCA from 31 dermatology departments in 11 countries, nickel allergy was reported to be $20.7 \%$, ranging from 9.7 to $32.2^{9}$. In other study Uter et al. ${ }^{10}$ published the $2005 / 2006$ results of ESSCA. In this study they analysed their data based on geographic regions of Europe. Nickel was again the leading allergen. Sensitivity to nickel was $20.8 \%$ in Western Europe, $24.5 \%$ in southern Europe, $19.7 \%$ in central Europe and $22.4 \%$ in northeastern Europe. Recently, Uter et al. ${ }^{11}$ published the data of patients consecutively patch tested between 2009 and 2012 in 12 European countries with fragrance allergens contained in the baseline series were collected by the ESSCA network. They noticed that contact allergy to fragrances is common throughout Europe, with regional variation probably being explained by patch test technique, and differences in exposure and referral patterns. Although prevalence varies, other studies from various countries around the world almost invariably reported nickel as the most common sensitizer ${ }^{12-15}$

Sensitivity to nickel has been found to be associated with ear piercing ${ }^{16}$. Implementation of the nickel-exposure regulations in some countries had the effect of protecting the population from becoming allergic to nickel ${ }^{17,18}$. Our results and the results of previous studies from our country indicate that nickel allergy is common in Turkey and similar implementations may be helpful in limiting allergy to nickel in our country.

Cobalt chloride was the second most common sensitizer in our study. Sensitivity to cobalt chloride was also more common among women. Similarly, other studies from Turkey and several studies from different countries reported high rate of sensitization with cobalt chloride ${ }^{2-4}$. Cobalt is present as a contaminant in nickel, cobalt oxides, present as traces in cement. High rates of sensitivity to cobalt chloride may be in part due to nickel containing products and in part due to occupational exposure among construction workers. Cobalt sensitivity is generally lower in countries where nickel and cement regulations are in effect for a long time $e^{5,6,9,10}$.

Potassium dichromate was the third among sensitizer in our study. Most important source of dichromate as a sensitizer is the cement. Previous studies from our country also reported potassium dichromate to be one of the most common sensitizers. This was explained by the expansion in the construction industry in parallel with the increasing population and the inadequacy of protective measures among workers. In Eastern European publications, dichromate is often the leading allergen, however, it is quite low in Northern European countries 5,6,9,10. These countries implemented regulations to lower the concentration of soluble chromium by adding ferrous sulphate to cement decades ago. According to EU Directive 76/769/EEC (CONSLEG: 1976L076916/03/2004) these regulations took effect in all European Union countries. This regulation will probably lower the dichromate sensitivity within Europe in the future. Our results and previous studies indicate that similar regulations should be extended to developing countries to reduce dichromate sensitivity. Leather products are another important source of dichromate sensitivity. Some of the dichromate sensitivity especially in females may be due to frequent use of leather products in our country.

Following metal allergens (i.e. nickel, cobalt and chromium) thiuram mix was the fourth most common sensitizer in our study. The chemicals in thiuram mix are used as additives in manufacturing rubber products such as gloves, kitchen utensils, clothing etc. It has been found to be a frequent sensitizer among housewives and hospital workers in previous studies ${ }^{2,19}$

Paraphenylenediamine (PPD) allergy is mostly attributed to hair dyes. PPD has been reported to be the most frequent occupational allergen for hairdressers in Turkey and it has been reported among the most important allergens in the multicenter study of ESSCA in Europe ${ }^{2,9}$. In a recent study it is also reported to be a frequent allergen in Hong Kong. In this study, among the adult population, allergy to PPD was found to be more frequent among the patients aged 41 years or older, which was consistent with the exposure to PPD in permanent hair dyes in the middle-aged and older ${ }^{13}$. Recently, Onder and Adisen ${ }^{20}$ reported that PPD is the second most frequent allergen among patients aged 9 to 16 years in a Turkish population. They attributed allergy to PPD in this age group to frequent use of temporary henna tattoos. Our findings also indicate that PPD is an important allergen in Turkish population.

Although relatively low, formaldehyde was another important allergen in our study. In Europe, allergy to formaldehyde has been lowered since its use in cosmetics was largely abandoned and, as a disinfectant, it has been partly replaced by other compounds. Lazarov ${ }^{14}$ argued that another source of allergy to formaldehyde could be textile products treated with formaldehyde resins, and this might be also true for our patients since textile is an important industrial branch in Turkey. Frequencies of contact allergy to paraben mix, fragrance mix and $\mathrm{N}$-isopropyl-N-phenyl-p-phenylenediamin were relatively low, ranging from 1 to $2 \%$, and other allergens caused contact allergy in less than $1 \%$ of the patients. Fragrance mix has been found to be an important allergen in European, North American and Israelite studies $70,12,14,21$. Other previous studies from Turkey also reported low frequencies of fragrance allergy ${ }^{2-4}$. This may be due to less cosmetic and perfume use in our country.

\section{Study Limitations}

The study was done in Ankara Turkey. This situation caused the results to be limited to a certain region. Studies to be carried out with more patients in the wide geography will contribute more to the literature. Another limitation of the study was that the clinical correlation of the tests, ie the relationship between exposure and positivity, was not examined.

\section{Conclusion}

This study provides additional information about the contact allergens in Turkey. It should be noted that Turkey is a large country and there are considerable social and economic differences between regions, and the whole country is changing rapidly. More studies from different centers and in different time intervals will give us additional information on contact allergens and how the contact sensitization is changing over time.

\section{Ethics}

Ethics Committee Approval: The study was approved by the Gülhane Military Medical Academy Command Ethics Committee (approval number: 314, date: 09.07.2015). 
Informed Consent: Informed consent forms were taken before the study.

Peer-review: Externally peer-reviewed.

\section{Authorship Contributions}

Surgical and Medical Practices: A.Y., Concept: M.T., E.Ç., Design: A.Y., Data Collection or Processing: M.T., Analysis or Interpretation: E.Ç., Literature Search: A.Y., Writing: A.Y., M.T.

Conflict of Interest: No conflict of interest was declared by the authors.

Financial Disclosure: The authors declared that this study received no financial support.

\section{References}

1. Uter W, Johansen JD, Orton DI, Frosch PJ, Schnuch A. Clinical update on contact allergy. Curr Opin Allergy Clin Immunol 2005;429-36.

2. Akasya-Hillenbrand E, Ozkaya-Bayazit E. Patch test results in 542 patients with suspected contact dermatitis in Turkey. Contact Dermatitis 2002;46:1723.

3. Akyol A, Boyvat A, Peksari Y, Gürgey E. Contact sensitivity to standard series allergens in 1038 patients with contact dermatitis in Turkey. Contact Dermatitis 2005; 52:333-7.

4. Ertam I, Turkmen M, Alper S. Patch-test results of an academic department in İzmir, Turkey. Dermatitis 2008;19:213-5.

5. Nielsen NH, Linneberg A, Menne T, et al. Allergic contact sensitization in an adult Danish population: two cross-sectional surveys eight years apart (the copenhagen allergy study). Acta Derm Venereol 2001;81:31-4.

6. Dotterud LK, Smith-Sivertsen T. Allergic contact sensitization in the general adult population: a population-based study from Northern Norway. Contact Dermatitis 2007;56:10-5.

7. Bruynzeel DP, Diepgen TL, Andersen KE, et al. Monitoring the European standard series in 10 centres 1996-2000. Contact Dermatitis 2005;53:146-9.

8. Uter W, Hegewald J, Aberer W, et al. The European standard series in 9 European countries, 2002/2003- First results of the European surveillance system on contact allergies. Contact Dermatitis 2005:53:136-45.

9. ESSCA writing group. The european surveillance system of contact allergies (ESSCA): results of patch testing the standard series, 2004. J Eur Acad Dermatol Venereol 2008;22:174-81.
10. Uter $W$, Rämsch $C$, Aberer $W$, et al. The European baseline series in 10 European Countries, 2005/2006-results of the European surveillance system on contact allergies (ESSCA). Contact Dermatitis 2009;61:31-8.

11. Uter W, Gefeller O, Giménez-Arnau A, et al. Characteristics of patients patch tested in the european surveillance system on contact allergies (ESSCA) network, 2009-2012. Contact Dermatitis 2015;73:82-90.

12. Wetter DA, Davis MD, Yiannias JA, et al. Patch test results from the mayo clinic contact dermatitis group, 1998-2000. J Am Acad Dermatol 2005;53:416-21.

13. Lam WS, Chan LY, Ho SC, et al. A retrospective study of 2585 patients patch tested with the European Standard series in Hong Kong (1995-99). Int J Dermatol 2008:47:128-33.

14. Lazarov A. European standard series patch test results from a contact dermatitis clinic in Israel during the 7-year period from 1998 to 2004. Contact Dermatitis 2006;55:73-6.

15. Bajaj AK, Saraswat A, Mukhija G, Rastogi S, Yadav S. Patch testing experience with 1000 patients. Indian J Dermatol Venereol Leprol 2007;73:313-8.

16. Nakada T, lijima M, Nakayama H, Maibach HI. Rôle of ear piercing in metal allergic contact dermatitis. Contact Dermatitis 1997;36:233-6.

17. Jensen CS, Lisby S, Baadsgaard O, Vølund A, Menné T: Decrease in nickel sensitization in a Danish schoolgirl population with ears pierced after implementation of a nickel-exposure regulation. $\mathrm{Br} J$ Dermatol 2002;146:636-42.

18. Schnuch A, Uter W. Decrease in nickel allergy in Germany and regulatory interventions. Contact Dermatitis 2003:49:107-8.

19. Machovcova A, Dastychova E, Kostalova D, et al. Common contact sensitizers in the Czech Republic. Patch test results in 12.058 patients with suspected contact dermatitis. Contact Dermatitis 2005;53:162-6.

20. Onder M, Adisen E. Patch test results in a Turkish paediatric population Contact Dermatitis 2008;58:63-5.

21. Freireich-Astman M, David M, Trattner A. Standard patch test results in patients with contact dermatitis in Israel: age and sex differences. Contact Dermatitis 2007;56:103-7. 